\title{
The Djerdap National Park - The Polyfunctional Center of the Danube Basin
}

\author{
Stankovic, $S .^{*}$
}

Abstract National parks are of special significance among numerous forms of protected natural and cultural heritage. This does not only result of their number and size, but also of their multiple significance for science, culture, schooling, upbringing, education, recreation, tourism and protection of natural ecosystems. World's experience in this matter, as well as that of our country should be used more thoroughly in order to emphasize polyvalence and multiplication of useful functions of national parks for the benefit of the majority. A national park is an area of exceptional beauty where ecosystems are not endangered by human actions. With their specific morphological characteristics they represent national treasure for current and future generations. Djerdap, with its series of specific characteristics, stands out among the five national parks in Serbia. Proclaimed a national park in 1794, it nowadays occupies the area of 63,680.45 hectares on the territory of the boroughs of Golubac, Majdanpek, Kladovo, and Negotin. The heart of the Djerdap national park is the $100 \mathrm{~km}$ long composite valley of the river Danube. The highest number of tourist attractions o the whole flow of the river Danube is concentrated here. The nature, archeological sites, remains of Roman buildings, sacral objects, the lake, dams, hydro-electric power stations, villages and towns, people and events emphasize the polyvalence of this part of the Danube basin. This is why it should be given priority in development plans.

Key words The Djerdap national park, polyvalence, polyfunctional, science, culture, tourism, archeological inheritance, and reserves.

* Stevan Stankovic, Faculty ofGeography, University of Belgrade, Yugoslavia, Belgrade, Studentski trg 3/III
$\mathrm{H}$ istory of nature protection is abundant of events that are mentioned even today: in London the regulation of restriction the destructive influence of smoke and ash was made in 1273 , the bill on protection of elk and wild horse dates back to 1499 and some forests and endemic species of trees were protected in Russia in 1703. Alexander von Humboldt, explorer of vast areas of our planet, was among the first who initiated protection of nature for scientific purposes. He was considered the first to use the term " natural monuments" for specific natural rarities.

Turning point in organized protection of larger natural complexes is 1872, when National park Yellowstone, the first of its kind, was formally established in the USA. The explanation of the project emphasizes its purpose for the people and their pleasure. Soon, Royal National Park in Australia (1879), Banff National Park in Canada (1885), and Tangariro National Park in New Zealand (1894) were formally established. The first national park in Europe, Engadine in Switzerland, was formally established in 1914. On that occasion, it was stated that its flora and fauna are to be completely naturally developed and protected from any human influence. The first national parks in Montenegro (Durmitor, Lovcen, Biogradska gora) were proclaimed in 1952, and the first national park in Serbia, Fruska gora was proclaimed in 1960.

One of the characteristics of the post war period was fast increase in number of national parks in the world and in our country. In 1948, International Association for Nature Preservation was formed and shortly after Economic Social Council of the OUN concluded that national parks are of great importance for human culture and science, of corresponding economic and tourist importance, therefore it is necessary to preserve original nature in the parks. At the first world's conference on national parks (Seattle, USA), pedagogical, scientific and research significance of national parks was emphasized. Thus, their polyvalence and polyfunction, importance for human life, relaxation, physical and mental recreation was confirmed. Arrangement and usage of national parks has to be based on scientific truths in order to preserve ecological relationships.

This basic definition of a national park has been completed through time. Finally, in 1969 in New Delhi at the meeting of International Association for Preservation of Nature and Natural Resources, it was concluded that a national park is a large territory of exceptional beauty where one or more ecosystems are unchanged by human actions and where flora and fauna, geological and morphological characteristics are of great importance for science, upbringing, education and recreation. National parks are cared for by highest state's institutions, which by appropriate laws patronize the preservation of the area. (Stankovic, M.S. 2000).

\section{The Danube and \\ Protected Objects}

The Danube is a $2,783.4 \mathrm{~km}$ long river. Its basin covers the area of $871,000 \mathrm{~km}$ what is $8.5 \%$ of Europe or 8 times larger than Yugoslavia. On the Danube itself, its riparian area and basin there are numerous and versatile protected natural and anthropogenic objects and natural units of heterogeneous importance. At Yugoslavian sector on the Danube there are numerous river islands with specific ecosystems, well known as ornithology stations. Of special interest is the Upper Danube Nature Reserve, which is situated on the territory of Sombor, and Apatin. It covers the area of 9,996ha and it has been under protection since 1982. It includes two ornithology reserves Bestrement (9.63ha, protected in 1987), Mosorin marsh (35.66ha, 1971), natural wealth of Kardjordjevo (2,955.33ha, 1997), nature reserve Tikvara (508ha, 1977, revised in 1996), huge and multifunctional National Park Fruska gora, which is exposed to the Danube with its northern and eastern part (25,392ha, 1960, revised in 1993), and other 11 mon- 
uments of nature. Downstream there are special nature reserve Koviljsko -petrovaradinski marsh (480.6ha, 1997) and general nature reserve Deliblato sandy terrain (29,452ha, 1965), whose southeastern end is on the Danube bank (Kuzmanovic, J. 1997). However, according to its special features, importance and value, the Djerdap National Park stands out among the protected parts of the Danube and the Danube Basin.

\section{Special Features of the Djerdap National Park}

There are five national parks in Serbia. The largest one is the Djerdap National Park, which is situated in the northeastern part of Serbia on the left of the Danube and Djerdap Lake. It spreads on the Danube riparian area from the Golubacki grad fortress to the hydropower plant Djerdap. Formerly it covered the area of 82,000ha in 1974, but by the revision in 1993 the area was reduced to $63,680.45 \mathrm{ha}$. According to international criteria it is considered a nature reserve. According to domestic criteria it is natural wealth of high importance (Group of authors, 1998). It includes parts of the territories of different municipalities: Golubac, Majdanpek, and Kladovo. Its northern border is the Danube, whereas southern border follows the watershed of the Danube and Pek, the highest parts of Liskovac, Veliki greben and Miroc. The border is not the separating zone but the one of joining and permeating. Thus, there are efforts to establish a unique national park, which would also include both riverbanks and the riparian area of the Danube, and Djerdap Lake in Romania. Modern trends of integration of objects and activities on the Danube and the Danube Basin comply with the efforts.

Basic natural value of the Djerdap National Park is the Djerdap gorge $(100 \mathrm{~km})$. It is a composite valley and precursor between powerful ranges of the Carpathian, connecting the Panonian with Vlasko-Pontijski area, Western and Central Europe with Eastern Europe and Asia. The largest number of natural values of high importance for tourism and other industrial branches is concentrated in the Djerdap National Park.

\section{Nature in the Djerdap National Park}

Natural features of the Djerdap National Park stand as a renewing part for its polyvalence and multifunction and being combined in various ways

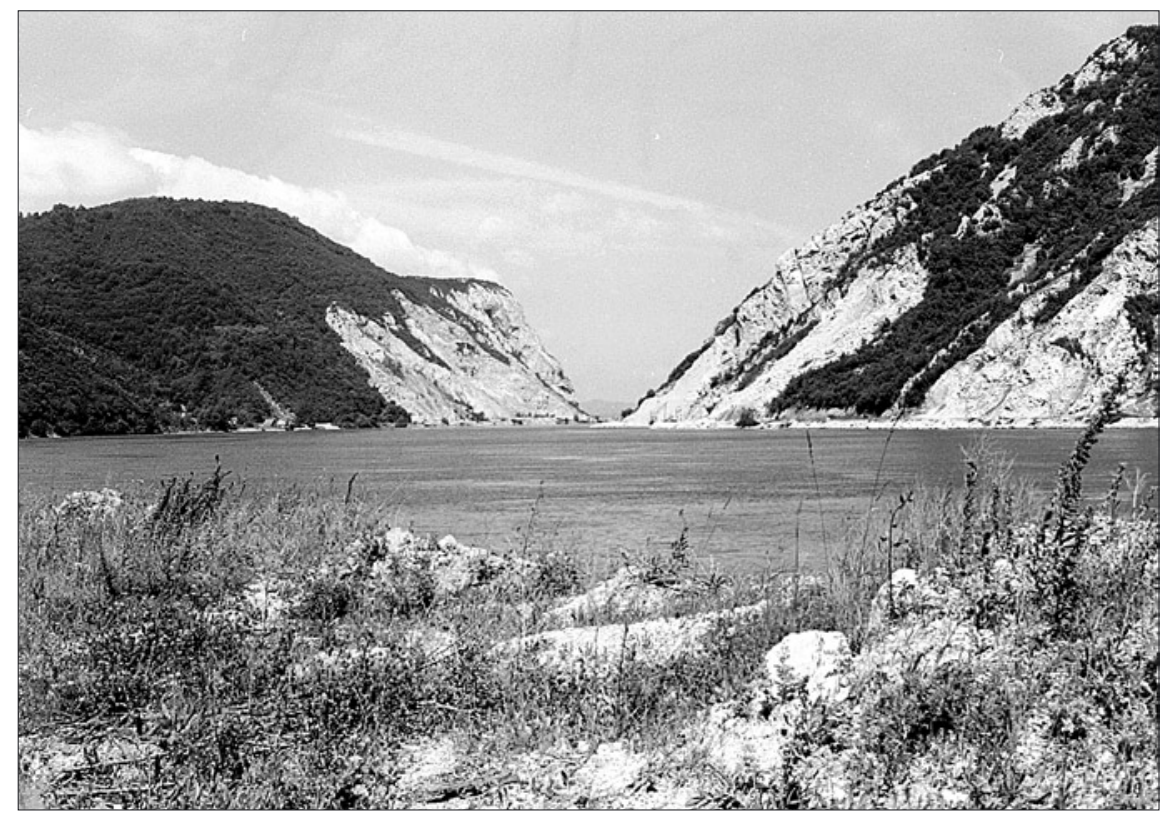

- Plate 1 Golubac or the Upper Gorge, the first narrowing point in the composite canyon of the Danube in the Djerdap Gorge. Some damages of the valley sides are noticeable due to the large complexes for exploitation of limestone, which is used as a building stone

they frequently compose unfavorable complexes. Those features are relief, hydrographic objects, climate, flora and fauna.

The Djerdap gorge is $100 \mathrm{~km}$ long, thus being one of the longest and most studied gorges in Europe. It belongs to the type of precursor gorges, i.e. antecedent river valleys, which are rare in the relief of our planet. The Djerdap gorge is composite, which makes it very attractive causing frequent changes of landscape on a short route. On the Danube sector of the Djerdap gorge, which may be identified as the Djerdap National Park, there are four narrowed points (canyons) and three widening points (valleys). The canyons and valleys of Djerdap are the following: Golubacka gorge, Ljubovska valley, Gospodjin vir gorge, Donji Milanovac valley, Veliki and Mali Kazan canyons, Orsava valley and the gorge of Sip.

The Golubacka gorge is the first narrowing point on the Danube in the Djerdap gorge. The length of this part of the gorge is $14,5 \mathrm{~km}$ and its height reaches $300 \mathrm{~m}$. The terrain consists mainly of carbonate rocks with numerous underground and surface relief forms. Then Ljubovska valley $(12 \mathrm{~km})$ excels in large area. The sides of the valley reach the height of $150 \mathrm{~m}$. Downstream the Ljubovska valley a short Gospodjin vir gorge appears, with steep slopes, which reach the height of $550 \mathrm{~m}$ featuring colossally above the Danube. At this sector of the Danube river, prior to the construction of the hydropower plant the largest river depth in Europe was measured. The Danube was $82 \mathrm{~m}$ deep. After the man-made lake had been made the level of water raised and the depth reached $90 \mathrm{~m}$ at the Gospodjin vir gorge. The largest tectonic-erosive broadening in the Djerdap is the spacious Donji Milanovac valley $(19 \mathrm{~km})$ downstream. The lake broadens up to $2 \mathrm{~km}$ in the valley as the prominent feature of the landscape. The Porecka river flows into the lake at the Donji Milanovac valley. At the river's mouth due to the raised level of water a spacious and deep bay was formed. Downstream the valley, the Danube flows into the most interesting part of the gorge, the narrow points Veliki and Mali Kazan, whose steep cliffs remind of intensive tectonic activity in this area. Near Romanian village of Dubovo, Veliki and Mali Kazan are physically separated by a broadened point, which corresponds to the morphological complexity of the area and contributes to its attractiveness for tourism. Veliki Kazan $(12 \mathrm{~km})$ excels with its rocky sides that reach height of $300 \mathrm{~m}$.Mali Kazan is the narrowest part of the Djerdap, only $180 \mathrm{~m}$ wide. Riparian area of Mali and Veliki Kazan is more easily accessed by waterway than by the road, thus certain parts remain invisible for the tourists traveling by car. Efforts for joining the most attractive tourist parts of the Djerdap with the nearest roads have to be made in order to enable longer stay of tourists, which would be in concordance with gaining higher economic effects. Some 
caves are to be subjected to the process of valorization as well as some strong limestone wells, which occur in this region. Downstream the Danube valley extends into $16 \mathrm{~km}$ long Orsava valley with mild easily accessed sides, suitable for weekend houses at dominant positions. The Djerdap gorge ends at the Sip narrowing point, $6,5 \mathrm{~km}$ long. The most suitable conditions for building a dam and hydro-energetic and navigating system were met at this sector near the island Crkviste. This is where the artificial lake Djerdap ends. The Flow of he Danube downstream the dam is rather slow due to the altitude and plain terrain. Near the island of Marul, a new dam with the system of canal locks, i.e. the new hydroelectric and navigating system "Djerdap II" is being constructed, which would increase tourist values of the Djerdap, and enable formation of new offer and richness of contents for the tourists (Stankovic, S. 1975).

Morphological variety of the Djerdap gorge contributes to performing of appropriate activities. Locations for construction of new objects are numerous and could be divided into three groups: by the lake, panoramic, and special. Locations by the lake are situated immediately on the lakeshores and they are suitable for the development of nautical, fishing and bathing tourism; panoramic locations are situated on extended slopes, capes and flat terraces and they are suitable for observation decks and catering objects; special locations are situated next to the fortresses, sacral objects, archeological sites, rural and urban settlements.

The largest hydrological potential of the Djerdap National Park is the lake, which was formed by building the hydroelectric dam and improving the conditions for navigation. The highest concentration of the Danube waterpower is in the Djerdap gorge, where the Danube makes a cataract of $30 \mathrm{~m}$ and accelerates to $3-6 \mathrm{~m} / \mathrm{s}$. Average water flow is between 5,800 and 6,000 $\mathrm{m}^{3}$ per a second. After the dam had been built and the lake formed, with the deceleration point of $69 \mathrm{~m}$, thus the conditions for navigation upstream and downstream were improved due to the flooding of the emerging rocks, whirlpools and "giant pots". The speed of water decelerated to $0,3 \mathrm{~m} / \mathrm{s}$.

The length of Djerdap Lake at the maximum water level is $264 \mathrm{~km}$ and at lower water level the length of the lake is $132 \mathrm{~km}$. Deceleration of the river is slightly noticed up to Belgrade and further up to Slankamen and even to the mouth of the river Karas. Due to the gorge and valley type of the Djerdap, the lake has variable morphometric indicators. The narrowest point $(180 \mathrm{~m})$ is at Mali Kazan, and the widest $(2 \mathrm{~km})$ at the Donji Milanovac Valley. At the points where the lower parts of the riverbed and valleys of former tributaries of the Danube were flooded, interesting bays were formed, suitable for nautical tourism (marines) as well as for equipping stations for fishing and hunting. The largest bay $(7 \mathrm{~km}$ long and $1 \mathrm{~km}$ wide at the lake) was formed in the valley of the Porecka river. Smaller bays were formed at the mouths of the rivers Pesaca, Ribnica, Zlatica, and Suva reka (Dukic, D. 1964).

According to the mean monthly temperature, which is above $18^{\circ} \mathrm{C}$, it is possible to bath in the lake in June, July, August, and September. On the other hand high air temperatures contribute to the long bathing season, although a restricting factor is increasing pollution of water. In addition, due to frequent amplitudes of the water level, beaches at he riparian area are difficult to be maintained. At low water level, there is plenty of mud on the shore and thus it is difficult even to enter the water at some places.

In winter the occurrence of ice at the lake's surface is possible. It obstructs the navigation, but it is mainly for a short period. The artificial lake "Djerdap II" would be spared of occurrence of ice and frequent amplitudes of water level and thus it would offer more favorable conditions for bathing tourism and navigation. Although it stretches over the borders of the Djerdap National Park, the lake would influence the increase of tourist values in various ways, because it could be complementary valorized. Low flat and easy accessible coasts, miniscule amplitudes of the water level and clear water would prevail as a new tourist value.

Apart from the lake itself there are other hydrographic motifs in the Djerdap National Park, most of which belong to the Danube river system. Due to the insignificant quantity of precipitation, the rivers and brooks lack water, which is caused by limestone terrain enabling abundance of groundwater. That is why the river systems of the tributary rivers are small. Average density of the river network is 980 $\mathrm{m} / \mathrm{km}^{2}$ of the park territory, where the most density is in the river system of the Zlatica river $\left(1,420 \mathrm{~m} / \mathrm{km}^{2}\right)$. A part of the Porecka river system is included in the Djerdap National Park and the river Porecka, which is made by joining the rivers Crnajka and Saska between mountains Deli Jovan, Stol and Veliki Krs flows into the lake downstream Donji Milanovac.

On the territory of the Djerdap National Park several springs and limestone wells were found. Those hydrographic objects should be analyzed in detail and some of them used as drinking water for the local people and the tourists.

In analyzing air temperature the data from meteorological stations in Veliko Gradiste, Tekija, Karatas, Brza Palanka and Turn Severin were used as well as the data from atlas of climate in SFRY. At those stations temperatures exceeding $20^{\circ} \mathrm{C}$ were recorded in July and August and in Veliko Gradiste and Turn Severin also in June. Those temperatures enable 4 months long bathing season. Autumn is warmer than spring and more suitable for tourist trips and stays in the Djerdap National Park. The lowest mean monthly air temperature at all meteorological stations was recorded in January. At the riparian area it is about $-1^{\circ} \mathrm{C}$ and at the highest parts of the Djerdap National Park about $-4^{\circ} \mathrm{C}$, whereas mean air temperature measured in the warmer period is $18^{\circ} \mathrm{C}$.

There are 300 to 320 days a year with air temperature higher than $0^{\circ} \mathrm{C}, 240$ to 260 days a year with air temperature higher than $5^{\circ} \mathrm{C}, 180$ days (170 days in the higher area) a year with air temperature higher than $10^{\circ} \mathrm{C}$ in the Djerdap National Park. The number of 120 to 160 days with air temperature higher than $15^{\circ} \mathrm{C}$ corresponds to the summer period. There are 100 hot summer days a year with air temperature higher than $25^{\circ} \mathrm{C}$ in the lower area, whereas in the higher area there are 50 days. The number of tropical days with the air temperature above $30^{\circ} \mathrm{C}$ is 30 in the riparian area and 20 in the higher area. The best period for tourists' visits to the Djerdap National Park is from mid May until end of September, when the air temperatures exceed $15^{\circ} \mathrm{C}$, what is with other favorable climatic elements of special value for tourism. (Group of authors, 1972) 
Relative air humidity in the Djerdap National Park has increased due to the large surface of the lake itself and significantly afforested area. The air humidity reaches its maximum in December and its minimum in August. Increased air humidity causes lower insolation. It has been estimated by observations made in Negotin, although they are not precise for the Djerdap National Park, that annual insolation is 2,050 hours. Due to the variability of exposition this should be taken into consideration when locations for activation of the Djerdap National Park are discussed. The same should be applied for the features of the winds and periods of silence.

Precipitation is observed at several meteorological and rainfall stations. The data for the period between 1951 and 1980 enable a detailed survey of the pluviometric regime. The outstanding fact is that precipitation in the Djerdap National Park is 200 to $300 \mathrm{~mm}$ less than mean precipitation for Yugoslavia.

The number of days with precipitation height above $1 \mathrm{~mm}$ is $80-90$; and above $10 \mathrm{~mm}$ it is 25 to 30 . Precipitation of high intensity, when the rainfall is above $20 \mathrm{~mm}$, occurs only 6 to 8 times a year. The highest frequency of precipitation is in May and June, and the lowest in August and September.

The first snow occurs in December, and the last at the beginning of April. Mean height of snow by Djerdap Lake is $30-40 \mathrm{~cm}$ and in the higher areas it is $60 \mathrm{~cm}$. The snow cover above $10 \mathrm{~cm}$ lasts for approximately 30-40 days a year; the snow cover of $30 \mathrm{~cm}$ lasts for only 5 days a year in the lowest parts in the Park, whereas in the highest part it lasts for 20 days. The snow cover above $50 \mathrm{~cm}$ is considered a rare occurrence and it lasts for only 6 to 10 days a year.

One of the characteristics of the Danube sector in the Djerdap is increased cloudiness, which is one of the restricting factors for touristic travels. According to the data obtained at meteorological stations in Veliko Gradiste and Tekija, the highest cloudiness is observed in November and December, when it exceeds 7.7 or 8.1 tenths of the sky covered in clouds. The lowest cloudiness measured in August for Veliko Gradiste is 3.9 and for Tekija it is 3.5 tenths of the sky covered in clouds. Low cloudiness occurs also in September and July, which in concordance with optimal values of other climatic

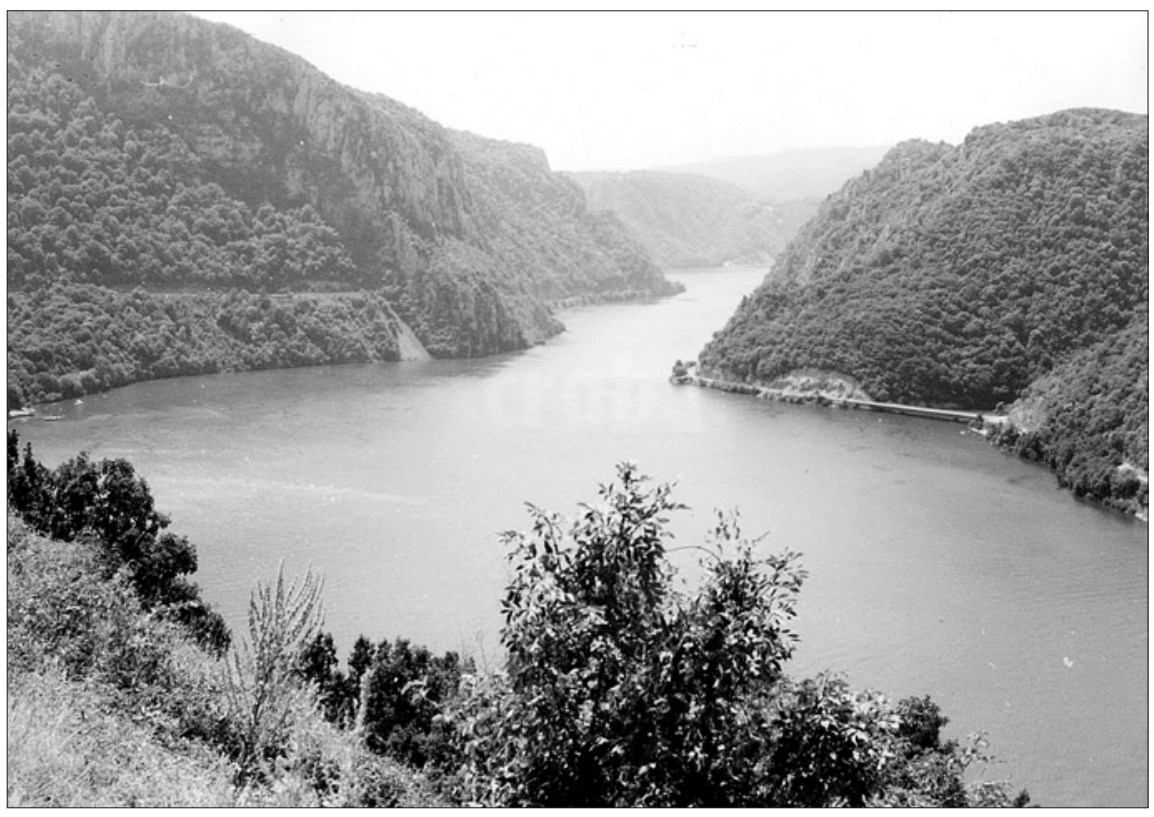

Plate 2 Traditional national building was dominant in the settlements of the Danube riparian area, prior to the construction of the dam for the power plant "Djerdap" and raising the level of the river. Two reconstructed houses are situated at the entrance of the archeological locality Lepenski vir

elements of interest for recreational, nautical, land travel and stationary tourism.

The most frequent and strongest wind in the Djerdap National Park is Kosava, which blows in winter obstructing water and land traffic that has negative effect on touristic travels. In summer there are a lot of days without wind and with significant insolation.

The basic vegetation in the Djerdap sector at the Danube, especially the National Park is forest. Forest phytocenoses excel with stability and high level of reproduction due to favorable natural conditions. Complexity and versatility of forest and shrubs vegetation, prominent differences between flora and fauna of limestone and of silicate rocks as well as the differences between vegetation of gorges and vegetation of valleys are the main characteristics of the Djerdap National Park. There are more than 50 species in the forests and shrubs in the Djerdap National Park, among which the dominating two: beech (forming montane forests) and oak tree (growing mainly in mixed woods), which is the result of continental climate and specific edaphic conditions of the habitat, especially slope terrain and exposition.

Certain parts of the Djerdap National Park are characterized by polydominating and deteriorated forest communities. Some of them have been discovered for the first time in Europe. Manu relict forest communities are rarely found in Serbia. That is why the Djerdap National Park is rightfully claimed to clearly reveal the origin, development and differentiation and well as different processes of degradation of vegetation. For the purposes of constantly developing tourism, protection and improvement of vegetation are imposed as a special obligation.

According to current flora researches, there are over 1,000 different plants in the Djerdap National Park, many of which being relicts, and thus contributing to attractiveness and curiosities of our country which is of great importance for touristic propaganda. Relict species in the Djerdap National Park are yew-tree, butcher's broom, maple tree, Turkish hazel, hackberry, and barberry (Misic, V. 1980).

The Djerdap National Park and its surroundings are well known by large number of animal species. Otter, deer, fox, ermine and boar are found in lowland and flooded forests as well as white stork, small white heron, and white tailed eagle. In beech and oak tree forests deer, wildcats, beech marten, edible dormouse, pine marten, and squirrel are found. Birds are well represented with booted eagle, forest owl, stock dove, short-toed eagle, lesser spotted eagle, and scops-owl. Relict and mixed type forests are the habitat of deer, rabbit, beech marten, pine marten, squirrel, sparrow hawk and owl. The steep rocky and limestone sides are the habitat of pine marten, skunk, partridge, wild pigeon and other birds, whereas farming areas and meadows 


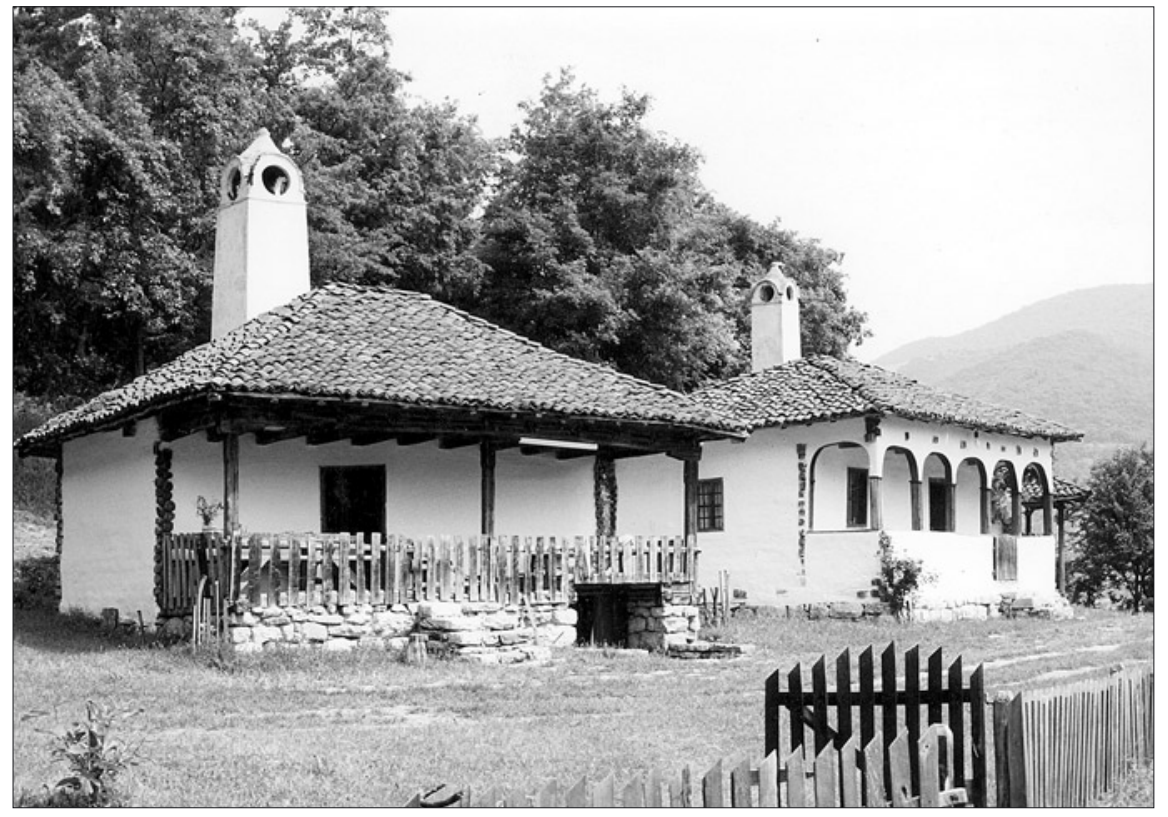

Plate 3 The narrowest part of the $100 \mathrm{~km}$ long Djerdap Gorge is called Kazan. The width of the aquatic territory of great Djerdap Lake at this point is only $180 \mathrm{~m}$ and its depth $68 \mathrm{~m}$. Several observation decks and protected locations represent unique tourist attraction

are the habitat of rabbit, fox, weasel, skunk, badger, quail, stock dove and etc.

\section{Cultural and Historical Heritage of the Djerdap National Park}

The Djerdap National Park comprises cultural historical monuments from the Neolithic Period to modern times. Cultural heritage shows that the Danube riparian area was inhabited in the Neolithic Period and since then it has preserved the continuity of living. The development of the living in this area may be traced at archeological sites of back to Roman, Turkish and modern buildings.

The first archaeological researches at the Danube terrace near Lepenski vir have only shown a miniscule part of the wealth to be found at the site. In 1967, beneath the settlement of farmers and cattle farmers (5300 to 4800 years ago), material traces of culture of world's importance were found. At seven large, successively built settlements of fishermen, hunters and food collectors, planned shelters, graves, stone and bone tools, jewelry and tablets with engraved signs resembling letters and sculptures in stone were found. It was estimated that those traces date back to 5300 BC. It also brought knowledge that the communities inhabiting the area established complex natural and social relationships, extraordinary style architecture and made sculptures in large pebbles. Lepenski vir emerged at the archeological map o Europe as a unique cultural center of great importance. (Srejovic, D. 1969).

For several more settlements dating back to the time of Lepenski vir and later centuries that were found at Djerdap await for the scientific estimation and possibilities of being included new road and completion of open-air and museum exhibitions would contribute to higher importance of Lepenski vir and the Djerdap National Park in the tourist offer.

Hajducka mill is an archeological site at the foot of Mali Strbac. The remains of pre-historic settlement and works in ceramics were found there. They date back to the Neolithic Period. The remains of a building from Ancient Period were found in the vicinity. Pecka swamp is situated at the foot of Veliki - Tekija road. The remains of prehistoric settlement were found there. Mrfija - Mosna is a locality near the village Mosna, in the Porecka river valley. Archeological researcher confirmed the remains of a prehistoric settlement there.

The remains of a necropolis from late Bronze Age were found at the locality of Veliki Gradac. Locality Tekija, next to the settlement Tekija is famous for the remains of a large building, next to which a marble tablet with the inscription in Latin was found. It dates back to the time of Roman Empire. Trajan's tablet and road date back to $100 \mathrm{BC}$, representing the symbol of great human in the tourist offer. Construction of the Strbac, on right of the Donji Milanovac efforts in constructing the road through a rock near the Danube. The tablet was placed in honor of Trajan, who was building the road by the Danube as a continuation of formerly started Tiberian road through the Djerdap gorge and finished it in $103 \mathrm{BC}$. The road was of great strategic importance. Due to the construction of the dam, the level of Djerdap Lake rose and Trajan's tablet was moved out the reach of water, but remained unreachable for the tourists to present days which is unsustained for the tablet is a monument of historical and civilization value. The traces of Roman fortifications were found at Malo Golubinje and Veliko Golubinje, at later some objects from Byzantine Period were also found. Visible remains of fortification from Roman Period were found in the Porecka riverbed, near its mouth into Djerdap Lake. Similar buildings existed near Gradac and Mali Gradac, where the base of a small Roman castle, used during the First Serbian Rebellion, was found. Locality Banja near Donji Milanovac is insufficiently explored. It is possible that Roman thermals and some objects from Turkish Empire existed at this locality. Roman and Byzantine remains were found at Ciglana and Ribnica localities. At the entrance of the Djerdap National Park from Belgrade direction, there is Golubacki grad, a unique fortress. It was first mentioned in 1337, when it was under jurisdiction of knez Lazar. After the Turkish conquest of Serbia, the fortress was under jurisdiction of Turks. It was abandoned in the $19^{\text {th }}$ century. Despite the fact that it is under protection its capacities are underused for the purposes of tourism and other manifestations (Trifunovic, L. 1969).

\section{Protected natural reserves}

Within the Djerdap National Park eight nature reserves and one regional nature park are protected. At the same time they are the most interesting parts of the Djerdap gorge in the sense of natural sciences and tourism. Wellorganized tourism with versatile offer at these localities may increase their importance as complementary motif of visits and stays.

The nature reserves within the Djerdap Naitonal Park are the following:

Golubacki Grad covers the area of 24ha, including the medieval fortress of historical and cultural value. It excels 
with high shrubs of lilac, elm, and European ash. The forests of oak, beech, and nuts are unique in Yugoslavia.

Bosman-Sokolovac encompasses the riparian area in the Djerdap gorge. It covers the area of 281 ha where shrubs of lilac and Turkish hazel grow.

Bojana is a nature reserve of 27 ha with pure autochthonous forest of nut.

Coka njalta with Pesaca covers the area of 354ha of low shrubs of lilac and Turkish hazel.

Ciganski potok is a nature reserve of nut forest covering the area of 18ha.

Somrada is a nature reserve of 14 ha. It excels in relict coniferous species of holly.

The Boljetinska river gorge - Greben is a nature reserve covering the area of $100 \mathrm{ha}$. It is geological, geomorphologic rarity, stone cuts, which reach the Danube and flourish in fossils.

Lepenski vir is a nature reserve, which includes the archeological site with the same name. It covers the area of 21ha and it is famous for numerous relict flora species. It is also the frame of the oldest Neolith settlement in Serbia.

Regional Natural Park Veliki and Mali Strbac. It covers the area of 899 ha including the Danube riparian area where Trajan's tablet was placed. Its main characteristics are steep slopes, limestone relief, and forests.

These nature reserves point out immeasurable natural, cultural and historical wealth of the Djerdap National Park, enabling complex tourist offer for different tourist groups and thus they need to be better represented in tourist propaganda. As several more zones of protection will be proclaimed in the Djerdap National Park, the conditions for development of tourism become more favorable.

\section{Conclusion}

History of national parks in the world and in our country is long and versatile. Modern humanity needs protected complexes of nature and thus treats them with special care. Due to the range of specific features, especially of preserved ecosystems and culturalhistorical heritage, majority of national parks are characterized by polyvalence and polyfunctionality, i.e. they own various morphologic, hydrologic, climatic, biogeographic, archeological, monumental and ethnographic characteristics and therefore emphasize their numerous functions. From their basic

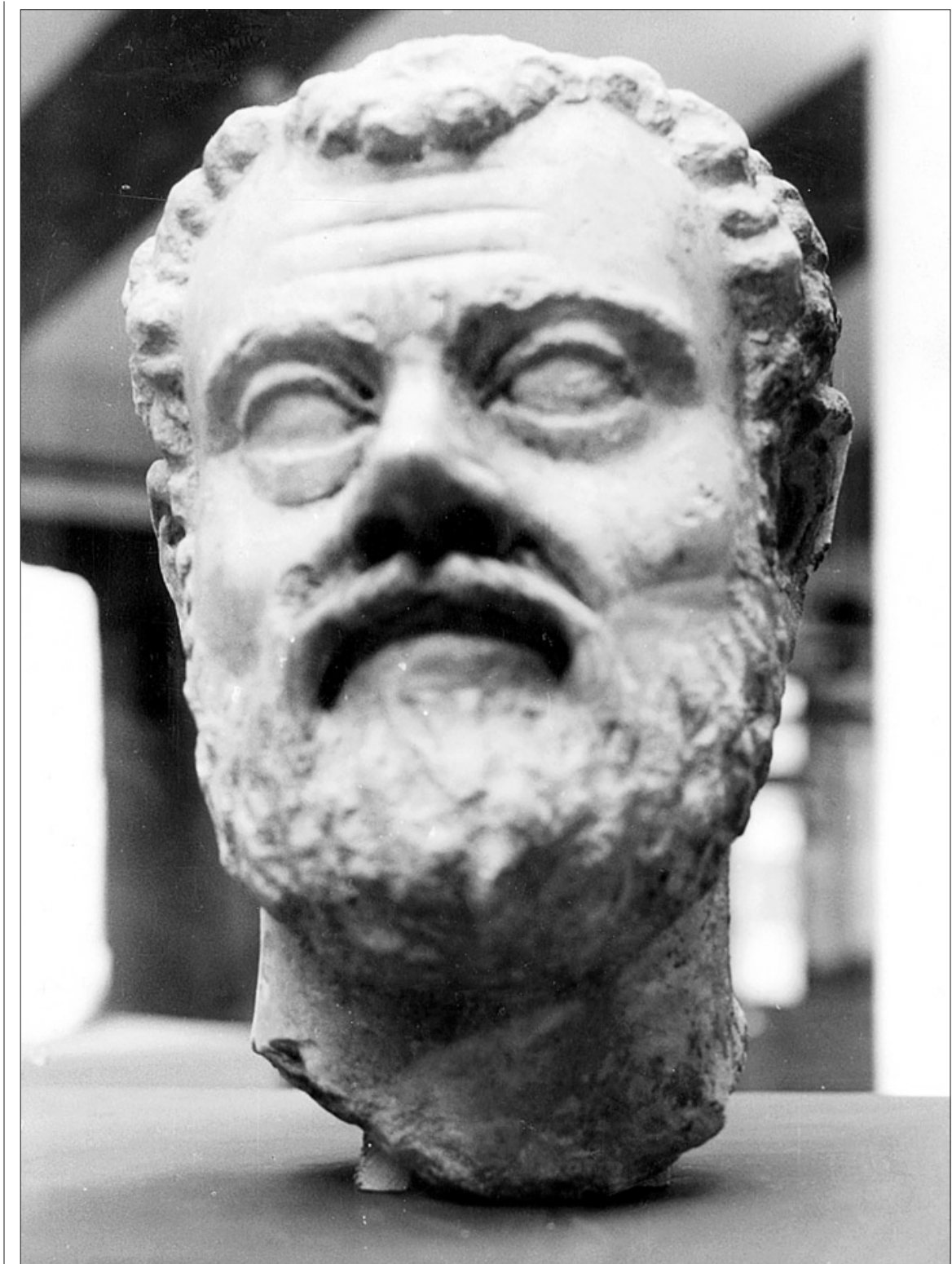

Figure 4 At the point where the Danube exits the Djerdap Gorge, the town of Kladovo is situated, where the Museum of Djerdap was open in 1997. Numerous items found in the Danube riparian area and Djerdap Lake in several decades of archeological researches are exhibited there. The sculpture of Roman imperator Albin, which was found in Diana, a large military complex situated $1 \mathrm{~km}$ downstream the power plant "Djerdap" and visited by tourists, attracts notice of visitors

function, protection and improvement of the area, with preservation of original flora and fauna and stability of ecosystems, other functions are derived, among which tourist, educational, and etc. some with emphasized economic character, whereas others with emphasized socially significant effects.

The Djerdap National Park, which comprises the river, the lake, the gorge, and mountainous surrounding and has a potential in water and land traffic, influences several economic possibilities in rural and urban settlements. That influence would result in additional funds for spatial planning, which is one of the priorities when development of tourism in Serbia is in question. In our Republic, which is continental area of the Balkans,
Djerdap Lake, as a part of the Djerdap National Park, is not only of local and regional value but also of national, European, tourism, energetic, traffic, cultural, historic, and civilization value. It seems that tourism, as an industrial branch, which connects the area, people and activities in an improved way, has to be designed and developed with special attention. In the Djerdap National Park there are excellent conditions for the development of many types of tourism, that are to be developed in concordance with other industrial branches and thus broadening the base for economy and valorization of natural and obtained wealth.

Djerdap Lake and its riparian area are constitutional parts of the Djerdap National Park, suitable for various 
types of tourism. Development of nautical tourism is possible due to the vast and calm surface of the lake, suitable for navigation of small and large ships. Docks at Tekija and Donji Milanovac, as well as canal locks at the dam enable safe anchoring of the ships and undisturbed navigation throughout the year. Austria and Germany seem to be the largest market for nautical tourism. Their tourists use their own vessels whereas tourists from Czech Republic, Slovakia, Hungary and Russia take organized tourist routes on the Danube.

One of the well-developed branches is excursion tourism. Most of the excursionists come from Belgrade, Vojvodina, Sumadija, Pomoravlje and Eastern Serbia to visit the archeological site Lepenski vir and the dam with the hydropower plant Djerdap. The highest intensity of excursions occurs in May, June, September and October. The offer of the excursions is becoming richer, the plan now including the visit to the hydropower plant "Djerdap II" which is in construction. The accommodation facilities are mainly to be found in the "Karatas" bungalows.

Stationary tourism is the most developed branch in Donji Milanovac and Tekija. The two settlements offer contemporary tourist and catering service. After the hotel "Lepenski vir" had been built, Donji Milanovac became the center of tourism at Djerdap Lake. Hotels, sports fields, dock, beach, restaurants, and other facilities as well as picturesque area, excellent position and vicinity of the dam, Lepenski vir, Klasovo, Majdanpek and Turn Severin, provide the necessary conditions for Donji Milanovac to function as a tourist center. Besides domestic tourists, groups of foreign tourist come from Germany, Austria, and Greece occupying the available accommodation capacities.

Manifestation tourism gives emphasis to organization of sports and cultural activities at the lake and in the vicinity of numerous cultural and historical monuments. Folklore is represented in the tourist offer in its original mixed form and as such it is attractive for the tourists. Different types of festivities may improve the quality of tourist offer and at the same time sustain the tourist season. Consequently, sports fishing at the lake and hunting in the mountains should be intensified.

A lot of young people take part in the tourism activities at Djerdap Lake developing the branch of youth tourism in that way. This type of tourism is to be further developed through the system of schools in the open and professional training in the nature. This may not only refer to the secondary school students but also to students of tourism, geography, biology, geology, hydromechanics, traffic and transport engineering, history of art, and etc. Youth tourism must not be observed only through its economic effects, but also through its non-economic functions, which are highly important, and therefore numerous forums should be supporting its development.

\section{References}

Dukić D. (1964): Đerdapska hidroelektrana. Glasnik Srpskog geografskog društva, sveska XLIV, broj 2, Beograd.

Grupa autora (1972): Atlas klime SFR Jugoslavije. Savezni hidrometeorološki zavod, Beograd.

Grupa autora (1998): Pet decenija Zavoda za zaštitu prirode Srbije. Zavod za zaštitu prirode Srbije, Beograd.

Kuzmanović, J. (1997): Zaštićena prirodna dobra u priobalju Dunava. Futura, knjiga 1, Agencija "Valjevac", Valjevo.

Mišić, V. (1980): Reliktna šumska vegetacija Nacionalnog parka Đerdapa i Tare. Institut za biloška istraživanja "Siniša Stanković", Beograd.

Srejović, D. (1969): Lepenski vir. Srpska književna zadruga, Beograd.

Stanković, M. S. (2000): Turistička geografija. Geografski fakultet Univerziteta u Beogradu, Beograd.

Stanković, M. S. (1975): Turistička valorizacija veštačkih jezera Srbije. Posebna izdanja Srpskog geografskog društva, sveska 41, Beograd.

Stanković M. S. (1985): Turističke vrednosti Đerdapskog jezera. „Vodoprivreda", broj 1, Jugoslovensko društvo za odvodnjavanje i navodnjavanje, Beograd.

Trifunović, L. (1969): Stare kulture u Đerdapu. Galerija Srpske akademije nauka i umetnosti, Beograd. 